\title{
Metallographic Investigations of the Premature Corrosion Failure of Steel Seam-Welded Galvanized Cold Water Pipes
}

\author{
Bogdan Pawłowski - Dorota Tyrala - Monika Pilch
}

Submitted: 30 December 2019/Published online: 16 January 2020

(C) The Author(s) 2020

\begin{abstract}
A premature corrosion failure in seam-welded galvanized steel cold water pipes was reported to occur after just 18-24 months in service. The aim of the present work was to investigate the causes of this premature corrosion of pipes, through metallographic investigations. This work comprised chemical analyses, visual examination of internal surfaces of pipes and microstructural examinations of the corrosion perforation regions (pitting corrosion areas) using optical and scanning electron microscopy with energy-dispersive $\mathrm{x}$-ray analysis. The investigations showed that failures resulted from incorrect installationpipes were installed with yellow brass ball valves. When mixed with yellow brass, galvanized steel triggers dezincification and results in electrolytic action when combined with nonferrous metals, such as copper and brass.
\end{abstract}

Keywords Galvanized steel pipes .

Premature corrosion failure $\cdot$ Water distribution system

\section{Introduction}

Iron and steel pipes have been used in water distribution systems for over five centuries [1]. Galvanized (zinccoated) steel was the dominant pipe material for most of the twentieth century and is still installed in buildings today. Economically, modern zinc-coated steel pipes are inexpensive and recyclable. With a long life span, such material is very attractive. Zinc coatings protect steel by providing a physical barrier as well as cathodic protection for the underlying steel. In this process, zinc, as a more

B. Pawłowski $(\square) \cdot$ D. Tyrala $\cdot$ M. Pilch

AGH University of Science and Technology, Kraków, Poland

e-mail: bpawlow@agh.edu.pl ignoble metal, acts as a sacrificial anode, while steel (as a cathode) is not attacked. However, there are many reports of galvanized steel water pipe failures due to corrosion after several months or few years of service life [2, 3]. Accelerated corrosion occurs under certain conditions of flow water chemistry. The internal wall of the steel pipe, exposed to aqueous environment (flowing water), usually suffers more severe corrosion (so-called internal corrosion) than the external wall exposed to indoor conditions [4]. Many water distribution systems begin to experience pinhole leaks caused by pitting corrosion on the internal surfaces of the piping. Zinc corrosion in flowing water is a complex process controlled largely by water chemistry and temperature. Relatively small differences in water chemistry can produce relatively substantial changes in corrosion products and rate. A coating of zinc protects galvanized pipe, but when corrosion occurs, it deposits high levels of zinc and iron into the tap water. A zinc coating on galvanized pipe may contain lead, copper, cadmium, chromium, aluminum, barium and other impurities. As a result of these impurities, corrosion of galvanized pipe may result in the release of trace metal concentrations [5-11]. Galvanized pipes are suitable only when the $\mathrm{pH}$ of the natural water is about 7 or moderately basic (between 8 and 12) [7].

According to the European Standards [12, 13], there are conditions under which galvanized steel pipes will sustain corrosion damage. One of the main factors influencing corrosion of zinc-coated pipes is water composition. The influence of chloride, nitrate and sulfate ions on pitting corrosion is determined by the so-called concentration ratio $\mathrm{S}_{1}$, the sum of chloride, nitrate and sulfate ion concentrations divided by the hydrogen carbonate ion concentration. According to these standards, pitting corrosion of zinc- 
coated steel pipes is extremely unlikely with $S_{1}$ below 0.5 and very likely with $S_{1}$ above 3 .

Contemporary regulations in many countries even prohibit the use of galvanized steel pipes in drinking water systems and do not recommend them for hot water circuits. Today, almost all installations in Denmark are built with stainless steel and polymeric materials pipes. In many other European countries, copper pipes are still widely used, and the use of hot-dip galvanized steel pipes is decreasing. In some countries, including Poland, galvanized steel piping is still popular, and this paper presents an investigation of cold water galvanized steel premature piping failure. Corrosion failure of seam-welded galvanized steel cold water pipes was reported to occur just after 18-24 months in service, and, according to the information from the installer, $S_{1}$ values determined in long-term measurements were below 0.5 .

However, this paper presents an unusual case when only cold water galvanized steel pipes corroded in the same internal water supply system, while hot water pipes made of the same galvanized steel showed no signs of corrosion.

\section{Experimental}

Failed galvanized (S195T) steel pipes with 60.3 and $76.1 \mathrm{~mm}$ diameters were examined. A Foundry-Master (WAS) spectrometer was employed for the chemical analysis, as shown in Table 1, which also reports the relevant standard. Photographs showing the inside surfaces of the 2 pipes were taken. Zeiss Axiovert 200 MAT light microscope and a scanning electron microscope FEI

Table 1 Chemical analysis of the investigated pipes, and EN 10255 standard, in wt.\%

\begin{tabular}{llcc}
\hline & & \multicolumn{2}{c}{ Pipe diameter } \\
\cline { 3 - 4 } Element & EN 10255 standard & $60.3 \mathrm{~mm}$ & $76.1 \mathrm{~mm}$ \\
\hline $\mathrm{C}$ & Max 0.20 & 0.12 & 0.09 \\
$\mathrm{Si}$ & $\ldots$ & 0.06 & $<0.005$ \\
$\mathrm{Mn}$ & Max 1.40 & 0.35 & 0.39 \\
$\mathrm{P}$ & Max 0.035 & 0.028 & 0.009 \\
$\mathrm{~S}$ & Max 0.030 & 0.005 & 0.005 \\
$\mathrm{Cr}$ & $\ldots$ & 0.005 & $<0.003$ \\
$\mathrm{Mo}$ & $\ldots$ & $<0.005$ & $<0.005$ \\
$\mathrm{Ni}$ & $\ldots$ & $<0.005$ & $<0.005$ \\
$\mathrm{Al}$ & $\ldots$ & 0.021 & 0.028 \\
$\mathrm{Cu}$ & $\ldots$ & 0.004 & 0.004 \\
$\mathrm{Nb}$ & $\ldots$ & $<0.002$ & $<0.002$ \\
$\mathrm{Ti}$ & $\ldots$ & $<0.002$ & $<0.002$ \\
$\mathrm{~V}$ & $\ldots$ & $<0.002$ & $<0.002$ \\
\hline
\end{tabular}

INSPECT S50, equipped with energy-dispersive spectrometry (EDS), were used to study microstructure and microcomposition, especially of the inner surfaces of the pipes.

\section{Results}

The chemical composition of the base steel as given in Table 1 meets the standard requirements for S195T steel. Typical macroscopic pictures of samples cut from the two perforated galvanized steel are shown in Figs. 1 and 2. The area marked in red in Fig. 2 was in close proximity to the screw connection pipe valve.

The microstructure of the base material of pipes is presented in Fig. 3 and is proper, typical for such steel grade (cross section near the pitting area). Metallographic examinations (not reported here) on transverse and
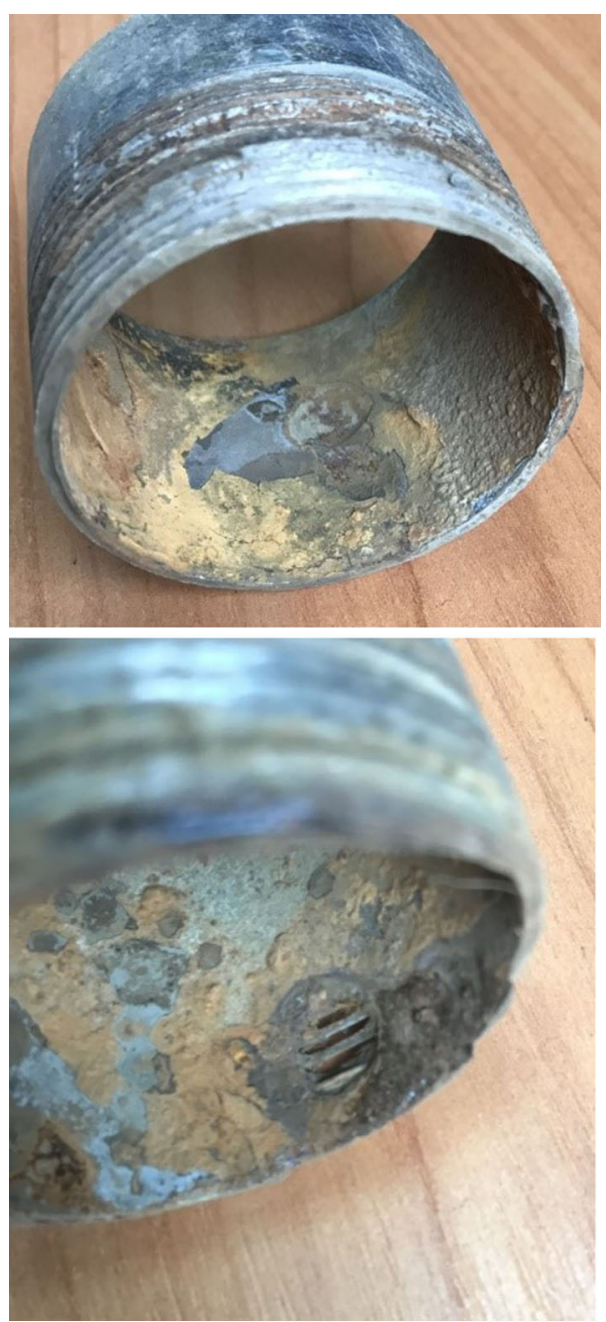

Fig. 1 Macroscopic view of samples of the 60.3-mm pipe 

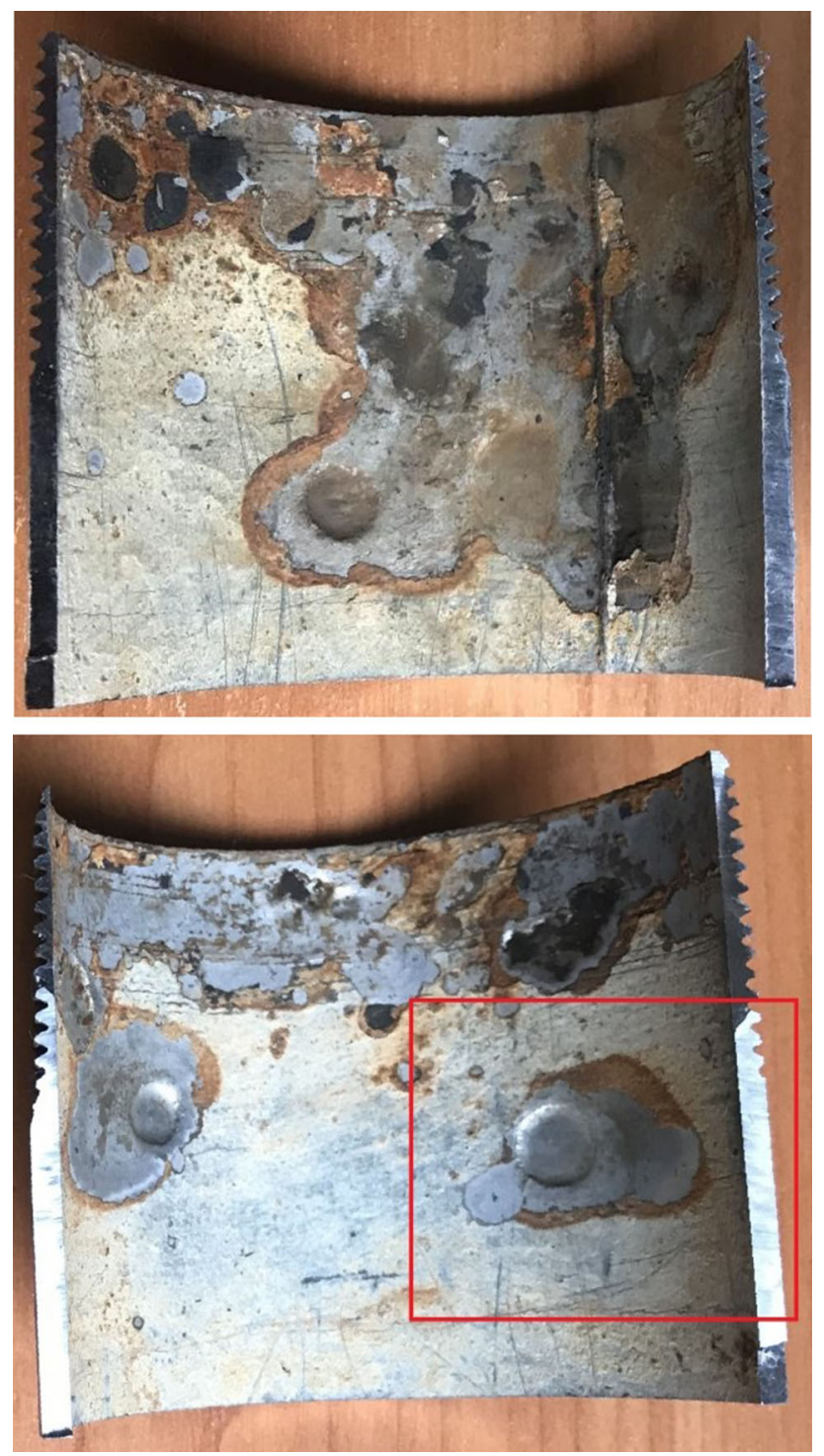

Fig. 2 Macroscopic view of samples of the 76.1-mm pipe

longitudinal specimens did not reveal any metallurgical defects or other irregularities in the microstructure.

The tested galvanized steel pipe inner surface samples (pitting area) were clean and almost free of corrosion products (oxides). Figure 4 shows a scanning electron micrograph of the sample shown in Fig. $2 b$ and shows that in this section of the pipe, near a yellow brass valve, pitting and shiny, silvery gray areas were observed in the vicinity of corrosive pits and in other examined sections. This demonstrates the purely galvanic nature of the formation of corrosion perforations in the studied pipe sections (socalled contact corrosion).
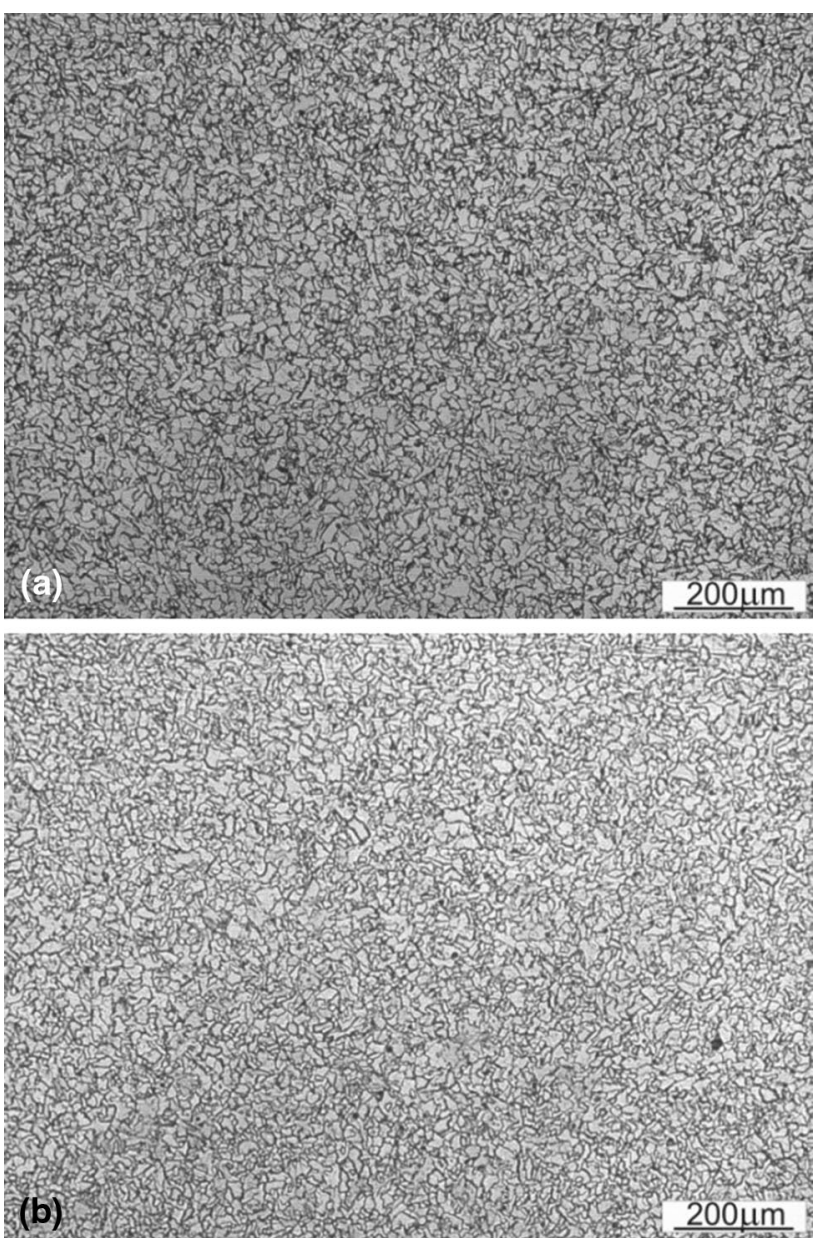

Fig. 3 The microstructure of the base material: (a) 60.3-mm pipe, (b) 76.1-mm pipe

The galvanic nature of the formation of corrosion perforations was confirmed by EDS X-ray microanalysis; the results are shown in Figs. 5, 6, 7 and 8. In the area of pitting (Fig. 6), the analysis revealed the presence of elements contained in the steel, practically without the presence of zinc. Similarly, for the pit vicinity area, only trace zinc content was revealed. The thin layer, visible at the bottom right of the micrograph (Fig. 7), is a residue from the original galvanized layer (iron-zinc), while further away (right side of the micrograph), there are general corrosion products (iron oxides, Fig. 8). 


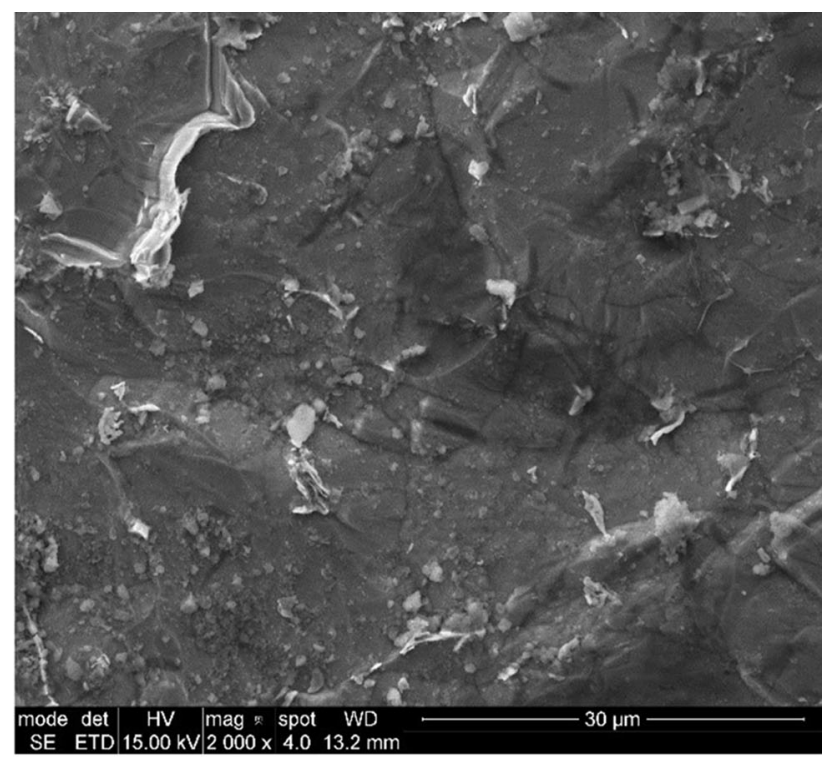

(a)

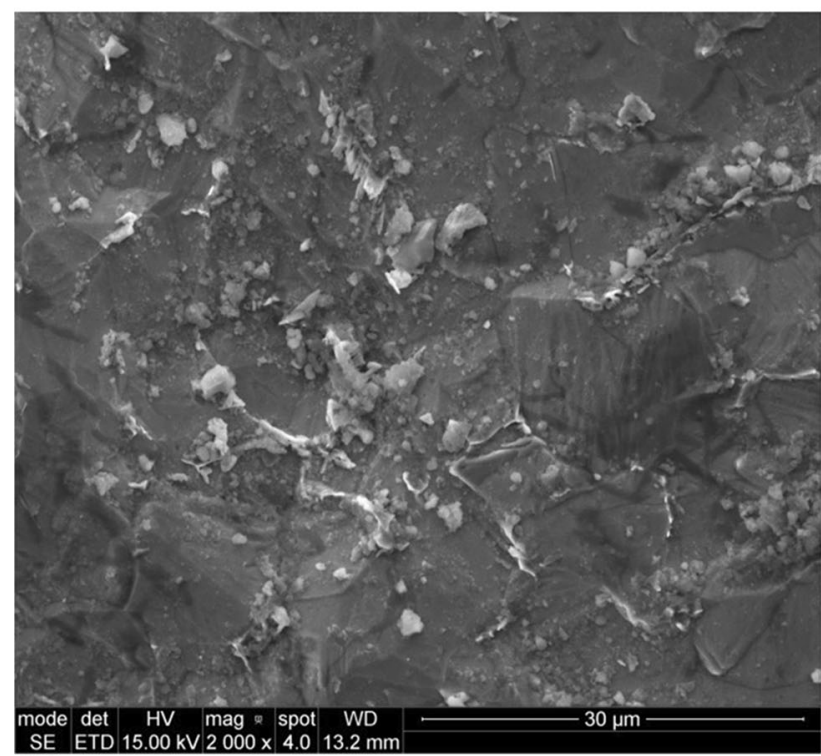

(b)

Fig. 4 Surface morphology of the pitting area of Fig. 2b: (a) pit, (b) vicinity region

\section{Discussion}

The bright, silvery gray areas present in the vicinity of the pits (Figs. 1,2) on the inner surface of galvanized steel pipes were also observed by other authors [14], but were apparently not thoroughly examined. In [14], only macroimages of such areas were shown.

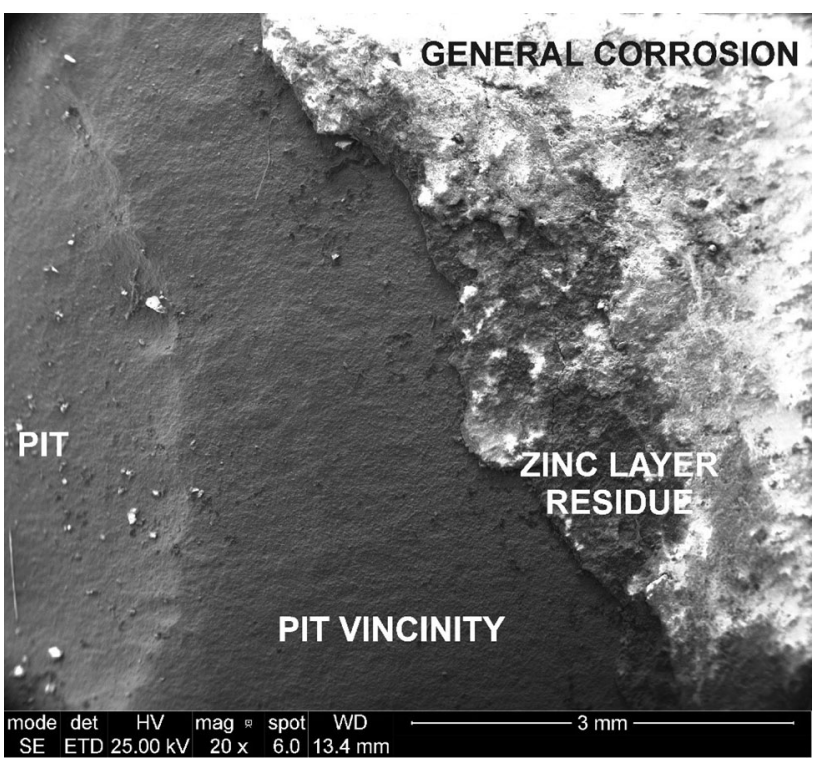

Fig. 5 The area of EDS microanalysis

As shown in Fig. 2, pitting in the examined cold water galvanized steel pipes occurred only in close proximity to the screw connection pipe valve. According to information obtained from the installation user, the examined cold water pipes were installed with yellow, in contrast to the hot water galvanized steel pipes where the nickel-plated brass ball valves were installed.

The use of yellow brass valves in direct electric contact with the galvanized steel pipes is a significant installation error, and it was the cause of the premature corrosion failure of the cold water zinc-coated steel pipes. The phenomenon called contact corrosion (bimetallic corrosion) occurs when two different metals are attached to one another (in this case, galvanized steel and yellow brass) and contact an electrolyte (flowing water). This results in different electrode potentials in the two metals with respect to the electrolyte. The base metal (zinc layer on the steel) is transformed into an anode, and this leads to the accelerated corrosion of that metal and inhibits the corrosion of the other, more noble metal (yellow brass), which is transformed into a cathode. This is what happened in the cold water galvanized steel pipes in the failed water supply system. When mixed with brass, galvanized steel triggers dezincification, and it results in electrolytic action $[9,10]$. 

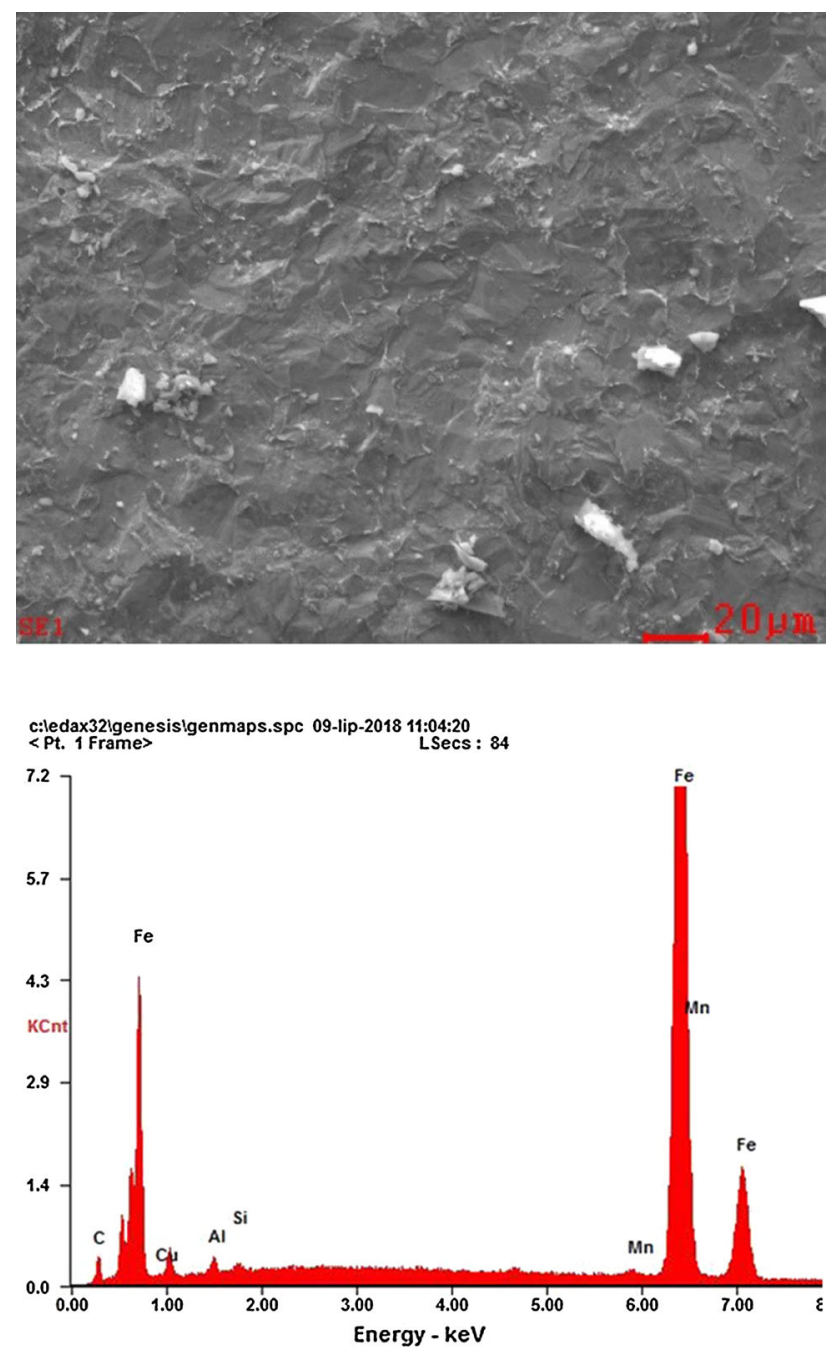

\begin{tabular}{|l|l|l|}
\hline Element & Wt\% & At\% \\
\hline CK & 05.48 & 20.95 \\
\hline CuL & 01.46 & 01.06 \\
\hline AlK & 01.23 & 02.10 \\
\hline SiK & 00.49 & 00.81 \\
\hline MnK & 00.61 & 00.51 \\
\hline FeK & 90.72 & 74.58 \\
\hline Matrix & Correction & ZAF \\
\hline \hline
\end{tabular}

Fig. 6 The results of EDS microanalysis in the pit

\section{Conclusion}

Corrosion failure of two seam-welded galvanized steel cold water pipes, occurring just after 18-24 months in service, was investigated. According to the installation user, $S_{1}$ values determined in long-term measurements were below
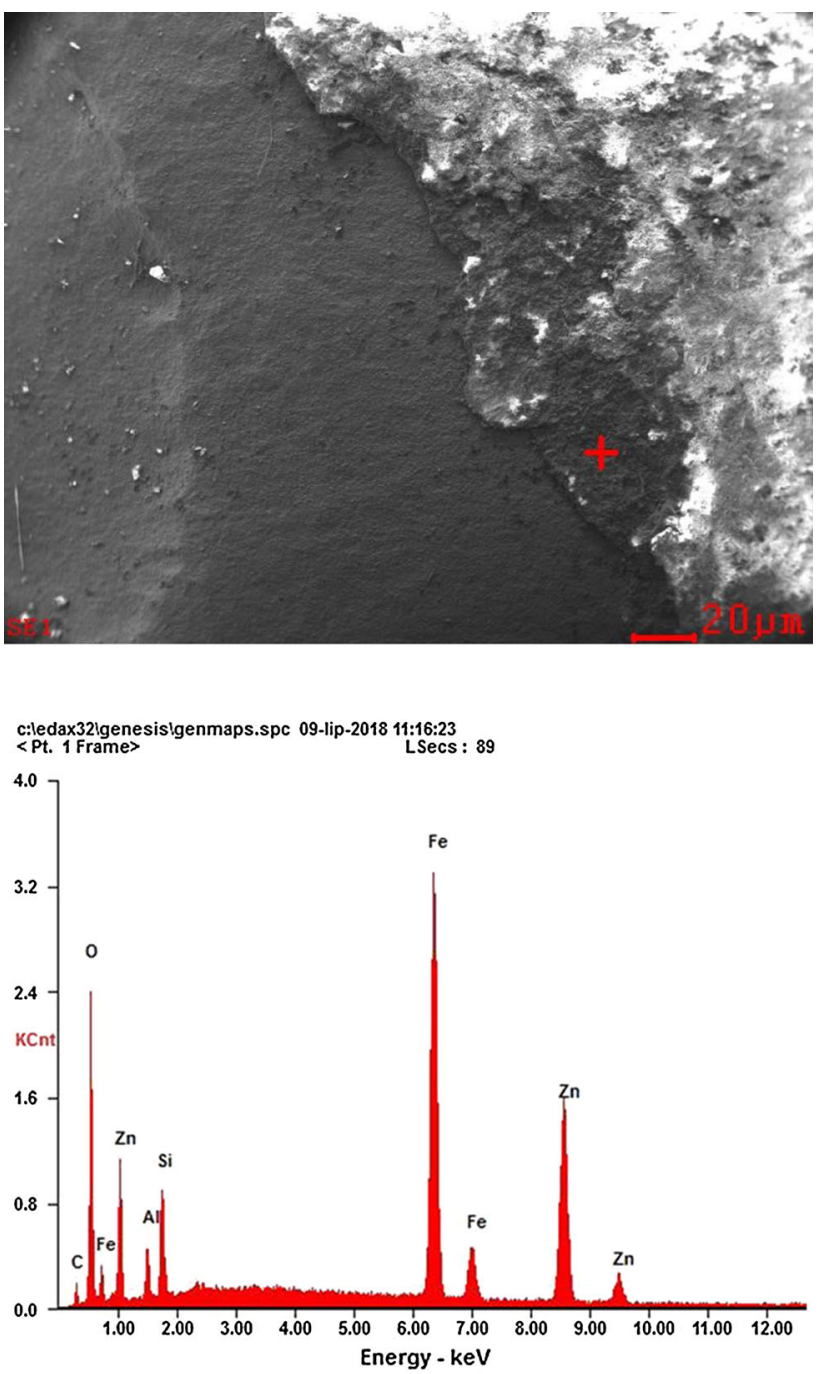

\begin{tabular}{|l|l|l|}
\hline Element & Wt\% & At\% \\
\hline CK & 04.33 & 12.29 \\
\hline OK & 17.95 & 38.22 \\
\hline AlK & 03.12 & 03.94 \\
\hline SiK & 05.37 & 06.51 \\
\hline FeK & 33.31 & 20.32 \\
\hline ZnK & 35.92 & 18.72 \\
\hline Matrix & Correction & ZAF \\
\hline \hline
\end{tabular}

Fig. 7 The results of EDS microanalysis in the zinc layer residue

0.5 (results not reported here) which justified the application of galvanized steel pipes in this water supply system. Microscopic and microanalytical examinations showed that the cold water pipe failures were associated with the use of yellow brass valves in direct electric contact with the galvanized steel pipes. This conclusion is additionally 

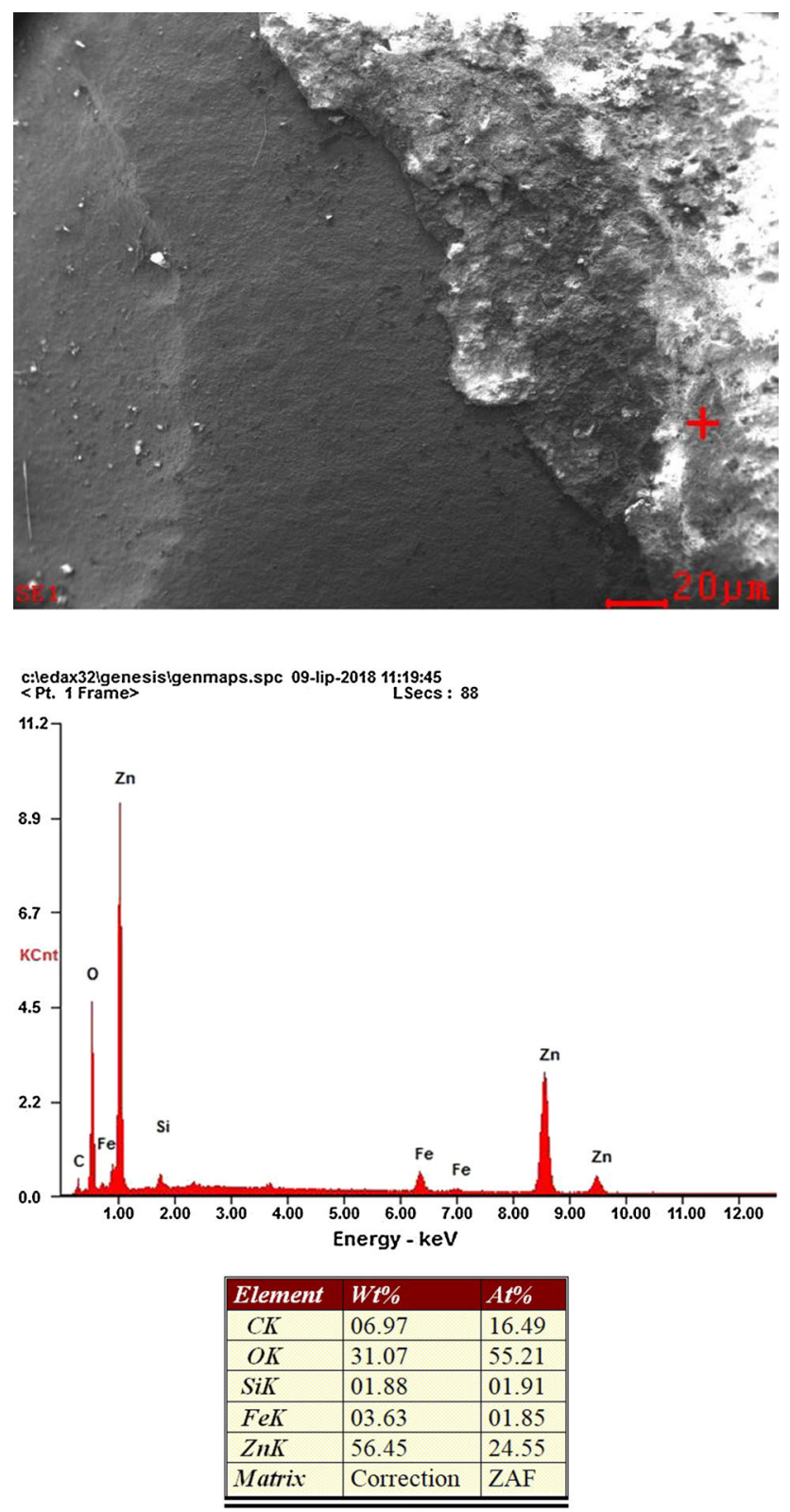

Fig. 8 The results of EDS in the general corrosion area

supported by the lack of signs of corrosion in the same galvanized steel pipes in hot water installation, where nickel-plated ball valves were used.

Open Access This article is licensed under a Creative Commons Attribution 4.0 International License, which permits use, sharing, adaptation, distribution and reproduction in any medium or format, as long as you give appropriate credit to the original author(s) and the source, provide a link to the Creative Commons licence, and indicate if changes were made. The images or other third party material in this article are included in the article's Creative Commons licence, unless indicated otherwise in a credit line to the material. If material is not included in the article's Creative Commons licence and your intended use is not permitted by statutory regulation or exceeds the permitted use, you will need to obtain permission directly from the copyright holder. To view a copy of this licence, visit http://creativecommons. org/licenses/by/4.0/.

\section{References}

1. P. Sarin, V.L. Snoeyink, J. Bebee, W.M. Kriven, J.A. Clement, Physico-chemical characteristic of corrosion scales in old iron pipes. Water Res. 35(12), 2961-2969 (2001)

2. B. Wilmot, R. Thompson, W. Barnett, Corrosion of hot dip galvanized piping used for re-circulating mine water. Hot Dip Galvaniz. Today 3(2), 33-37 (2006)

3. C.-H. Bae et al., Assessment of galvanized steel pipes for water service in buildings by direct diagnosis method. J. Water Supply Res. Technol. 56(5), 335-342 (2007)

4. D.F. Shams et al., Characteristics of pipe corrosion scales in untreated water distribution system and effect of water quality in Peshawar, Pakistan. Environ. Sci. Pollut. Res. 26(6), 5794-5803 (2019)

5. A. Colombo, L. Oldani, S.P. Trasatti, Corrosion failure analysis of galvanized steel pipes in a closed water cooling system. Eng. Fail. Anal. 84, 46-58 (2018)

6. F. Delaunois, F. Tosar, V. Vitry, Corrosion behaviour and biocorrosion of galvanized steel water distribution systems. Bioelectrochemistry 97, 110-119 (2014)

7. C.A. Della Rovere et al., Corrosion failure analysis of galvanized steel pipes in a water irrigation system. Eng. Fail. Anal. 33, 381386 (2013)

8. B. Pawlowski, J. Krawczyk, P. Bała, The premature deterioration of zinc-coated steel pipes in water distribution system. Int. J. Mater. Mech. Eng. 2, 43-47 (2013)

9. K. Slavíčková, A. Grünwald, B. Št'astný, Monitoring of the corrosion of pipes used for the drinking water treatment and supply. Civ. Eng. Archit. 1, 61-65 (2013)

10. T. DeVito, Phorgotten phenomena: corrosion control in drinking water plumbing-reminiscences of a water treatment specialist. Mater. Perform. 41(7), 42-43 (2002)

11. L.S. McNeill, M. Edwards, Review of iron pipe corrosion in drinking water distribution systems. Am. Water Works Assoc. 93, 88-100 (2001)

12. DIN 50930:2013 Korrosion der Metalle - KorrosionmetallenerWerkstoffeimInnern von Rohrleitungen, Behältern und ApparatenbeiKorrosionsbelastungdurchWässer (Corrosion of metals - corrosion of metallic materials under corrosion load by water inside of pipes, tanks and apparatus)

13. EuroNorm EN 12502-3:2005 Protection of Metallic Materials Against Corrosion-Guidance on the Assessment of Corrosion Likelihood in Water Distribution and Storage Systems

14. D. Živković, N. Mišina, P. Ljumović, Corrosion damage of seam welded galvanized hot water pipelines. Tehnički vjesnik 24(4), 1007-1012 (2017)

Publisher's Note Springer Nature remains neutral with regard to jurisdictional claims in published maps and institutional affiliations. 